\title{
The Parent Trap:
}

\section{An Inquiry Regarding Eugenics and Three- Parent Babies}

\section{Rebecca R. Fried \& Rebecca H. Liu}

\section{University of Western Ontario}

Among health professionals, 'biology and genetic endowment' is known to be one of the twelve key determinants of health. ${ }^{1}$ This determinant is, often jokingly, described as picking your parents, referencing the fact that many determinants of health can be altered to more favourable and healthful conditions, whereas genetics cannot. Individuals do not pick their parents and therefore, do not pick their genetic temperament. But, what if the reverse were possible, in that parents could pick their children?

\section{Designer Genes: A Discussion About Eugenics}

Often discussed in science fiction novels and films (e.g. Brave New World and GATTACA), the notion of parents 'picking' their children and altering genetics is anything but new. This topic, known as eugenics, is the process of manipulating genes to conceive children that possess specific, desirable traits $^{2}$. Eugenics has had a long and controversial history. Eugenics became greatly scrutinized during World War II, whereby the Nazis employed eugenics to justify the annihilation of millions of people ${ }^{2}$. Additionally, controversy surrounds the subject regarding beliefs of manipulation of nature (often deemed as 'playing God'). However, principles of eugenics have assisted with genetic screening and counseling, as well as fetal gene manipulation; and gene therapy for adults suffering from hereditary disorders ${ }^{2}$. The aforementioned examples highlight eugenics utility, in that adults with debilitating genetic illnesses have the ability to improve their health and to potentially lead normal lives ${ }^{2}$. As well, couples considering conceiving children are able to know what to expect with their children and prepare for the appropriate care.

\section{Three-Parents and A Little Baby}

The study of eugenics has acted as the catalyst for a new concept, 'Three-parent babies' (TPBS). The procedure, referred to as three-person in vitro fertilization or mitochondrial replacement therapy (hereafter referred to as TPIVF/MRT), occurs when one female wishing to conceive carries mutated mitochondria in their egg cell. Thus, TPIVF/MRT involves transferring nuclear DNA from an egg with mutated mitochondrial DNA, to a donor egg containing healthy mitochondrial DNA ${ }^{3,4}$. Once the donor egg is fertilized by a male sperm cell, it is argued that the resulting embryo has three parents, in a biological sense, due to the addition of the healthy mitochondrial DNA from the donor egg, which is passed down along with the mother and father's nuclear DNA ${ }^{3,4}$.

\section{It's All Down Hill: Negatives of TPIVF/MRT}

There are notable downsides to TPBS, the first being that the science is very new, and the efficacy of TPIVF/MRT is unknown. Evolutionary biologist Klaus Reinhardt posits that issues could arise if DNA from different women proved to be incompatible ${ }^{3,4}$. Reinhardt cited several experiments in mice, fruit flies, and other animals in which combining nuclear and mitochondrial DNA from individuals from different genetic backgrounds sometimes led to early death, reduced reproductive ability, rapid ageing, or reduced growth ${ }^{3,4}$. However, this point was countered by another scientist, Shoukhrat Mitalipov, arguing that those experiments were mainly completed by combining strains of inbred animals; and in reality, species such as humans from different genetic backgrounds interbreed freely without ramifications ${ }^{3,4}$. Additionally, there are debates on whether or not the genetic make-up of children born as a result of TPIVF/MRT will affect their emotional well-being when they realize they differ from children conceived from two parents ${ }^{5}$. These arguments among scientists, as well as the ethical issues raised, evince the fact that the science is too new to fully understand the full effects.

Up We Go: Benefits of TPIVF/MRT 
TPIVF/MRT has the potential to help hundreds of parents. Mitochondrial diseases affect one in 5,000 to 10,000 live births, suggesting that in the United States alone, between 1,000 and 4,000 children are born every year with mitochondrial diseases ${ }^{6,7,8}$. Although there is much controversy surrounding the use and efficacy of TPIVF/MRT, it is important to recognize that the entire premise is to prevent mitochondrial disorders such as: diabetes mellitus and deafness, muscular dystrophy, and Leigh syndrome ${ }^{7,8}$.

According to psychiatry professor Robert Klitzman, TPIVF/ MRT will save lives, not rewrite biology ${ }^{9}$. Klitzman argues that the media misleadingly portrays TPIVF/MRT as producing children with three parents; and a more accurate parallel would be to organ transplantation: "If I receive a kidney from a donor, no one says that I then consist of two people. One kidney, weighing perhaps 1-pound, now rests in my 185-pound body and allows me to live. Similarly, to replace less than one out of every 100,000 bits of DNA in an individual with DNA from someone else makes no major difference to the recipient's identity other than to allow him or her to survive" (paragraph 9).

Although many determinants of health can be indirectly altered to more favourable and healthful conditions, there is no direct control over genetics, which is why the notion of parents picking their children raises a variety of contentious scientific and ethical concerns. However, when the science of eugenics is strictly used to resolve debilitating genetic diseases, and to improve upon individuals' quality of life, TPIVF/MRT can be a valuable method in - at the very least - aiding in the development of a healthy child.

\section{References}

1. Public Health Agency of Canada. What determines health? [Internet]. Canada: Public Health Agency of Canada; 2011 [updated 2011 Oct 21; cited 2015 Feb 6]. Available from: http://www.phac-aspc.gc.ca/ph-sp/ determinants/index-eng.php

2. Wilson PK, Meloni S. Eugenics. In: Chauhan Y, Rogers K, Singh S, Tikkanen A, Young G, editors. Encyclopaedia Britannica Online Academic Edition [e-book]. United States: Encyclopaedia Britannica, Inc. 2015 [updated 2015 Feb 10; cited 2015 Feb 3rd]. Available from: http://www.britannica.com/ EBchecked/topic/195069/eugenics

3. Hayden EC. Regulators weigh benefits of 'three-parent' fertilization: But critics say mitochondrial replacement carries safety and ethical concerns. Nature. 2013; 502(7471):284-285.

4. Callaway E. The power of three: Techniques that transfer DNA from diseased human eggs to healthy ones - creating offspring with three biological parents - are on the verge of clinical use. Nature. 2014;502(7501):414-17.

5. Center For Genetics and Society. Inheritable genetic modification: 3-person IVF [Internet]. California: Center For Genetics and Society; 2015 [updated 2015 Feb 4; cited 2015 Feb 4]. Available from: http://www. geneticsandsociety. org/article. php?id=6527\#3

6. Tachibana M, Amato P, Sparman M, Woodward J, Sanchis DM, Ma H et al. Towards germline gene therapy of inherited mitochondrial diseases. Nature. 2013;493(7434):627-631

7. Haas RH, Parikh S, Falk MJ, Saneto RP, Wolf NI, Darin N, et al. Mitochondrial disease: A practical approach for primary care physicians. Pediatrics. 2007;120(6):1326-1333

8. Schaefer AM, McFarland R, Blakely EL, He L, Whittaker RG, Taylor RW, et al. Prevalence of mitochondrial DNA disease in adults. Ann. Neurol. 2008;63(1):35-39.

9. Klitzman R. Three parents, one baby? Not at all: Replacing mitochondria in an unfertilized egg will save many infants' lives, not rewrite biology. The Wall Street Journal [Internet]. 2015 Feb 9 [cited 2015 Feb 9] Available from: http://www.wsj.com/articles/robert-klitzman-three-parents-one-babynot-at-all-1423528082

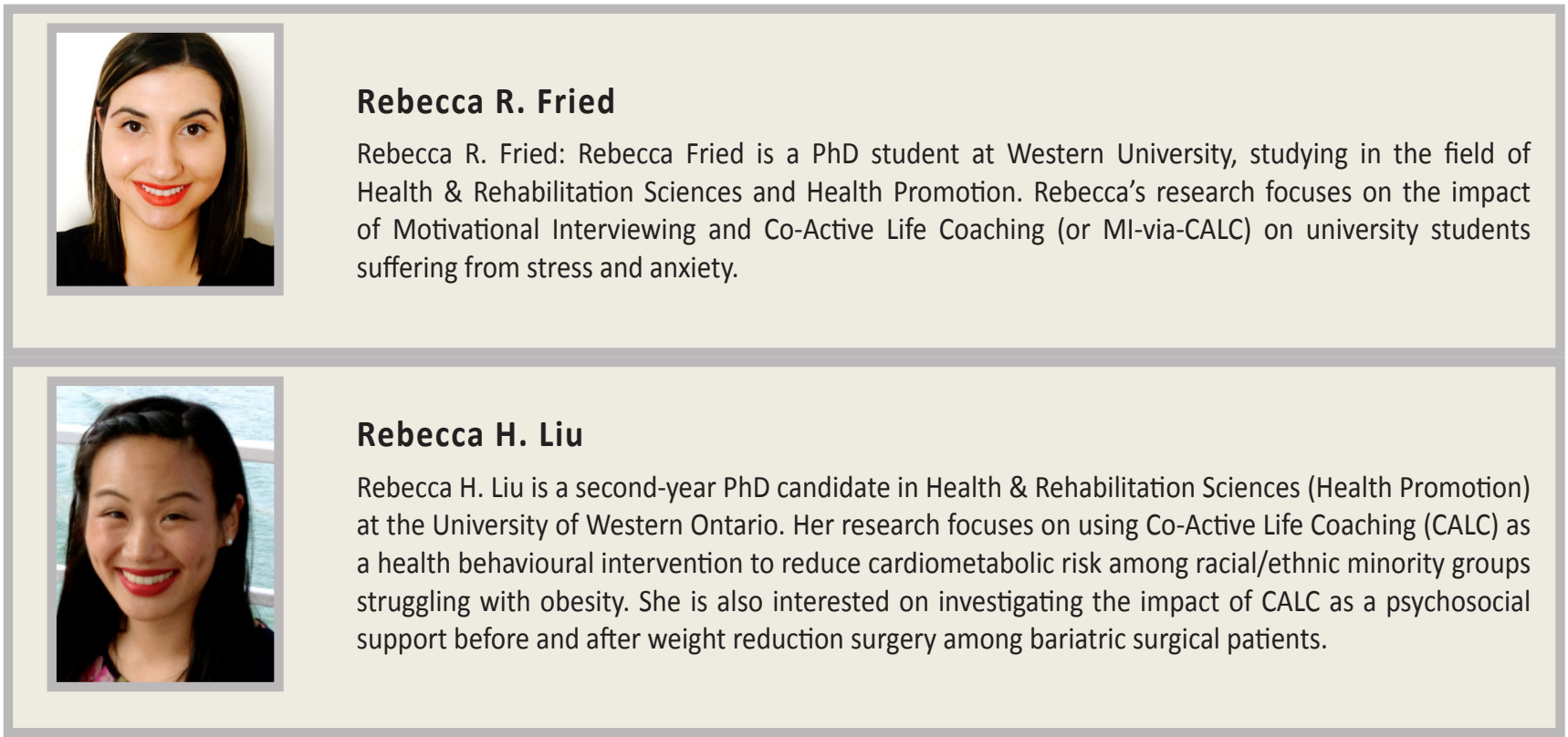

